\title{
Assessment of the Efficiency of Using Organic Waste from the Brewing Industry for Bioremediation of Oil-Contaminated Soils
}

\author{
Alexey V. Strizhenok ${ }^{1 *}$, Denis S. Korelskiy', Yosoon Choi ${ }^{2}$ \\ 1 Department of Geoecology, Saint Petersburg Mining University, Saint-Petersburg 199106, Russia \\ 2 Department of Energy Resources Engineering, Pukyong National University, Busan 48513, South Korea \\ * Corresponding author's email: alexeystrizhenok@mail.ru
}

\begin{abstract}
At present, the development and optimization of methods to eliminate the consequences of soil contamination with hydrocarbons is gaining increasing economic and social importance; it is the basis for sustainable development of the oil industry. Within the frames of the scientific research, a review of literature was carried out in the sphere of utilization of organic wastes from the food industry in reclamation of oil-contaminated soils; an experimental study of efficiency of the use of wastes from the brewing industry in the process of bioremediation of oil-contaminated soils was conducted and phytotoxicity of these wastes was determined. Experimental research was conducted at different initial concentrations of oil in the soil, which allowed to establish the optimal range of oil pollution level at which the efficiency of brewing waste use is the highest. Thus, at low concentrations (1000-2000 mg/kg), the dynamics of oil concentration decrease in the soil remained preserved throughout the whole duration of the experiment, and the efficiency of oil destruction in the soil exceeded $98 \%$, which confirmed the overall efficiency of application of brewing waste for reclamation of oil-contaminated soils.
\end{abstract}

Keywords: environment, sustainable development, oil-contaminated soil, bioremediation, organic waste, brewing industry, sparging, kieselguhr.

\section{INTRODUCTION}

Oil is one of the basic human needs in the modern world, which is exactly why the oil industry presently is among the most dynamically developing industries [Litvinenko et al. 2017]. The constantly increasing volumes of production, transportation, and storage of oil quite predictably lead to the intensification of land pollution, the environmental consequences of which can be critical both for humans and for natural ecosystems. In this regard, the balance between extraction of the required amount of hydrocarbons and preservation of a favorable environment is the basis for the sustainable development of the state and humanity as a whole [Pashkevich and Petrova 2016].

Oil pollution of soils is the cause of intensive transformations of morphological, physical, chemical, and biological characteristics of the soil, which lead to the disruption of the environmental balance in the soil biocenosis, decrease in the ability of soils to self-cleaning and self-recovery, inhibition of microorganisms, oppression or degradation of vegetation cover and depression of the functional activity of flora and fauna, changes in the structure of the soil, reduction of its aeration and drainage, disturbance of the water regime, changes in the oxidation reduction conditions [Akhmadiev and Rudakova 2013, $\mathrm{Xu}$ and Johnson 1995, Nizamzade 2014]. As a result, oil-contaminated soils are removed from economic circulation for decades, which does not allow them to be used as a natural resource [Alekseenko et al. 2018].

In addition, getting into the surface soil horizon, toxic components of oil can be accumulated, adsorbed, and transformed into even more toxic compounds, and subsequently involved in the cycle of biogenic substances, with which toxicants 
can enter the human body [Semin et al. 2017]. Toxicity of oil and petroleum products for living organisms is primarily associated with the damaging effect of these pollutants on cell membranes; in this regard, the increase in environmentally caused public health disorders is progressively more often associated with the escalating presence of hydrocarbons in the human environment [Agamuthu et al. 2010].

The main amount of oil gets into the environment during its transportation as a result of numerous accidents on pipelines. Every year, more than 50 thousand cases of breakthroughs of various origins are registered in the world, which leads to significant oil spills [Zambrano et al. 2018]. The analysis of accident frequency has shown that the leading positions have mechanical damages and damages caused by third parties; the second place have such types of damages as corrosion and operational errors; finally, the third place belongs to various natural phenomena, although those have the lowest frequency of occurrence [Gaysina 2016, Semyachko et al. 2018].

More than 65 thousand emergency oil spills are registered in the world every year. In the Russian Federation, the average number of emergency oil spills reaches 20 thousand per year, with more than 3 million tons of oil released into the environment [Welch 2014]. By the end of 2018, more than 5000 hectares of oil-contaminated soils have been taken into account in Russia, and only a little more than 800 hectares have been reclaimed [State report ... 2018]. This fact determines the high relevance of studies devoted to the development and optimization of methods for localization and elimination of oil spills, while eradication of the consequences of soil contamination with oil hydrocarbons, restoration of productivity and fertility of these lands are acquiring increasing economic and social importance in line with the concept of sustainable development of the oil industry [Kireev et al. 2014, Kovshov and Skamyin 2017].

Presently, the most commonly used methods of remediation of soils contaminated with oil hydrocarbons are mechanical, physicochemical, and biotechnological [Matveeva et al. 2018]. The two former ones accelerate the natural decomposition of oil and oil products by reducing the concentration but cannot ensure complete removal of oil products from the soil [Krauss and Wilcke 2007], since their high efficiency refers to oil concentrations in soils exceeding $10,000 \mathrm{mg} / \mathrm{kg}$ [Ibragimov et al. 2017]. In addition, many physicochemical methods are quite expensive. In recent years, mechanical and physicochemical methods more and more often are combined with or replaced by biotechnological ones based on the ability of soils to self-regenerate in the complex interaction of all types of soil organisms [Tsombueva 2014]. A promising biotechnological method for cleaning oil-contaminated soils is bioremediation; its essence is the use the biochemical potential of microorganisms (bacteria, fungi) capable of metabolizing a large number of various organic substances [Mukherjee and Bordoloi 2011]. The bioremediation technology provides for both the introduction of hydrocarbon-oxidizing microorganisms into the ecosystem [Yankevich et al. 2015] and stimulation of indigenous microbiota [Yatsenko et al. 2014]. It should be noted that the use of indigenous microbiota in the processes of bioremediation of soils contaminated with various toxicants is preferable, since autochthonous microorganisms faster adapt to the changed conditions in contaminated soils [Margesin and Schinner 1999].

Providing soils with biogenic elements is an important factor determining the intensity of oil decomposition [Pietron et al. 2017]. In addition to mineral and organic fertilizers, nutrient sources may include organic waste from the food industry. In Europe and North America seeking for alternative ways to process organic waste which would help reduce the amount of waste storage in dumps and landfills is quite active [Panchenko et al. 2018]. One of such ways is to use organic waste as ameliorant, a fertilizer additive, and a biostimulant to restore disturbed lands [Filonov et al. 2017].

In the scientific study, brewing waste was considered as an organic waste. The brewing industry is nowadays widespread in Europe and North America, while the amount of organic waste generated in the process of beer production is much higher than the demand for it. Despite the rich chemical composition of organic brewing waste, the main way of its utilization at present is direct storage in landfills, and only a small part of it is used as a feed additive for farm animals [Goswami et al. 2018]. Only in Russia brewing industry enterprises annually generate more than 1.5 million tons of organic waste, of which about $60 \%$ is stored in landfills [State report ... 2018].

Waste from the brewing industry mainly consists of organic substances of high humidity and 
is the source of a large number of organomineral compounds; in addition, it does not contain any poisonous substances, pathogens and helminth eggs [Dessalew et al. 2017].

In this regard, the main purpose of the scientific study was to assess the possibility of using organic brewing waste to improve the efficiency of bioremediation of oil-contaminated soils.

Waste from the brewing industry is a valuable secondary raw material with a high content of proteins, saccharides, lipids and mineral elements; it primarily consists of spent brewing grain (sparging), amounting up to $85 \%$, with the remaining $15 \%$ are composed of spent kieselguhr, residual yeast, malt sprouts, etc. [Goswami et al. 2018].

Sparging is the thick residues left after boiling and filtering barley wort. Sparging contains nondissolved components of barley or wheat malt: husk, coagulated insoluble protein, fats, polysaccharides and nitrogen-free extractives (NES). Sparging can serve as a biological substrate for the cultivation of entomopathogenic fungi Beauveria bassiana; besides, an alternative way for using sparging is its anaerobic fermentation with the formation of biogas [Dadashev et al. 2011].

Kieselguhr (diatomite) is a sedimentary formation of biogenic origin, consisting of fossil diatomic algae shells crushed into powder. The mineral composition of kieselguhr contains oxides of Al, Fe, Ca, Ti, Mg, Na, K and P. Kizelguhr has a fine porous structure and it has found ample application in many industries due to its high filtration and absorption capacity, heat and acid resistance, and chemical inertness. Kieselguhr is an integral component of brewing production, in the result of which kieselguhr mud, a waste of the brewing industry, is formed after the filtration of beer; it mainly consists of diatomaceous and organic substances sedated in the filtration process [Dessalew et al. 2017].

Kieselguhr, exhausted while filtration of beer, and sparging are considered biological waste and belong to the 5 th hazard class with trace content of heavy metals. For example, the content of mercury in dry sparging is less than $0.0025 \mathrm{mg} / \mathrm{kg}$, of cadmium is less than $0.1 \mathrm{mg} / \mathrm{kg}$, and lead is present in the amount of $0.18 \pm 0.06 \mathrm{mg} / \mathrm{kg}$ [Goswami et al. 2018].

The biochemical composition of sparging and spent kieselguhr is presented in Table 1 [Dadashev et al. 2011].

The review of literature identified several studies indicative of the potential of sparging as a
Table 1. Biochemical composition of crude brewing waste

\begin{tabular}{|l|c|c|}
\hline \multirow{2}{*}{ Biochemical composition } & \multicolumn{2}{|c|}{ Mass fraction, \% } \\
\cline { 2 - 3 } & Sparging & Kieselguhr mud \\
\hline Crude protein & 24,31 & 11,45 \\
\hline Crude lipids & 9,79 & 0,17 \\
\hline Crude fiber & 19,38 & 1,86 \\
\hline Ash & 5,09 & 75,27 \\
\hline $\begin{array}{l}\text { Nitrogen-free extractive } \\
\text { substances (NES) }\end{array}$ & 36,60 & 2,54 \\
\hline
\end{tabular}

source of nutrients, mainly nitrogen, for carbohydrating microorganisms.

Abioye et al. [2012] studied the process of biodegradation of used motor oil by organic waste. A high percentage of degradation was recorded in soil with the addition of sparging: $92 \%$ and $55 \%$ with $5 \%$ and $15 \%$ of contaminants, respectively. The implication is that the level of oil pollution affects the rate of biological decomposition of oil in the soil environment. We can conclude that sparging can act as ameliorant for deep cleaning of hydrocarbon-contaminated soil in case of low concentrations of contaminants.

The study of Oruru [2014] considers the issues of rational use of sparging in the process of bioremediation of soil contaminated with diesel fuel. The experiment had been conducted in laboratory conditions for 60 days; soil samples with concentrations of diesel fuel of $5 \mathrm{mg} / \mathrm{kg}$ and $10 \mathrm{mg} / \mathrm{kg}$ were examined, to which $10 \%$ of sparging were added; the concentration of diesel fuel in the samples with sparging was reduced by $95 \%$ and $90 \%$ respectively. The reason for this is the high content of nitrogen in sparging, which is a necessary nutrient for microbial activity.

Bacterization of sparging to accelerate the degradation of hydrocarbons of crude oil is described in the experiment of Senyene et al. [2017]. The experiment focuses on the combination of two approaches to bioremediation, i.e., biostimulation and bioaumentation. Actually, sparging acts as a biostimulant, while Bacillus subtilis works as a microbiological subculture. The results of the analysis showed that the best degree of degradation $(99.09 \%)$ was achieved in the sample with the addition of $1 \%$ of sparging and $20 \mathrm{ml}$ of Bacillus subtilis to soil contaminated with crude oil at $2.08 \%$ pollution level. With an increase in the amount of sparging and the level of pollution, the biodegradation of hydrocarbons degree gradually decreases. For example, the degree of removal of oil hydrocarbons at $2.6 \%$ level of pollution and 
the addition of $10 \%$ sparging was $97.13 \%$, while with an increase in the level of contamination by $4.16 \%$ and the addition of $20 \%$ of sparging it was $88.18 \%$.

Bio-stimulating potential of sparging for remediation of soils with old oil pollution was studied by Ogugbue et al. [2017]. The total content of oil hydrocarbons in the soil after 5 weeks of the experiment with sparging decreased by $57.7 \%$.

Robichaud et al. [2019] conducted field studies on bioremediation of soils contaminated with motor oil using organic waste. Wood shavings, sparging and horse manure were chosen as organic wastes. Based on the results of the experiment, the sample with sparging showed the highest moisture levels among all treatments, as well as high nitrogen content, but the amount of oxygen was not optimal.

Various aspects of the role of sparging and kieselguhr mud in the process of bioremediation of oil-contaminated soils are covered in detail in the work of Rudenko [2015]. Conducted laboratory and field experiments have shown that organic brewing waste increases the activity of enzymes of hydrocarbon-oxidizing microorganisms, accelerates the reduction of oil concentration, and improves the physical and chemical properties of chernozemic soils. The results of the study conducted at the experimental sites showed an increase in oil biodegradation by 1.12 times when secondary products of the brewing industry were introduced.

The possibility of using sparging as an ameliorant for sandy soils was reported in the research work of Russ et al. [2006]. The effect of sparging on the growth and development of corn and wheat has been tested through a series of experiments in the greenhouse and in the open air. Research shows that sparging, when fully mineralized, can provide large amounts of nitrogen. The content of phosphorus and magnesium in sparging is also relatively high (8.6 and $4.05 \mathrm{~g} / \mathrm{kg}$, respectively), but the amount of potassium is low $(1.40 \mathrm{~g} / \mathrm{kg})$. The introduction of sparging in the mass amount of $0.5 \%$ leads to an improvement in the water-retaining capacity of the soil; however, due to rapid mineralization, this effect is time-limited. Besides all, sparging is a good addition to other fertilizers.

According to the study of Song et al. [2011], introduction of kieselguhr helps to loosen the soil and improves its water-retention ability. Both effects lead to an increase in the activity of microorganisms. Quite possible is growth of mould on the surface of kieselguhr sediment, which can cause human diseases. To solve this problem, it was proposed to mix kieselguhr with quick lime, which reacts with the water contained in kieselguhr with a significant release of heat. As a result of a thermal reaction (about $100^{\circ} \mathrm{C}$ ), yeast is destoyed, and water is removed from the kieselguhr sediment, so that the end product is a powdery substance suitable for storage.

Dadashev et al. [2011] conducted research to produce organic and mineral fertilizers from kieselguhr mud and residual beer yeast. The essence of the study was the formation of compounds from brewing waste with wastes from various enterprises, such as enterprises of the chemical industry, construction materials and cement production. The authors proposed a technological scheme for the production of these fertilizers, including storage tanks, dosing scales, augers, mixing chambers, and granulators.

\section{MATERIALS AND METHODS}

Thus, the review of literature and the theoretical study of the chemical composition of brewing waste allowed the authors to put forward a hypothesis about the possibility of effective use of waste from the brewing industry to increase the efficiency of bioremediation of oil-contaminated soils. To confirm the hypothesis put forward, the following tasks and experiments were implemented:

1. Sampling of soil in the territory of oil spills liquidation with the use of mechanical, physical, and chemical methods without the use of bioremediation methods, and determination of the residual oil content in the selected samples for determination of investigated oil pollution ranges. Samples were taken by an envelope method from $0-10 \mathrm{~cm}$ layers in accordance with GOST 17.4.4.02-84 "Nature Protection. Soils. Methods of sampling and preparation for chemical, bacteriological, helminthological analysis" [GOST 17.4.4.02-84 ...]. The determination of the mass fraction of oil in the selected samples was carried out using the fluorimetric method of analysis according to the method HDPE F 16.1:2.21-98 "Quantitative chemical analysis of soils. Method for measuring the mass fraction of petroleum products in samples of lands and soils by the fluorimetric method of 
analysis using the "Fluorat-02" liquid analyzer" [HDPE F 16.1:2.21-98 ...].

2. Experimental determination of the efficiency of using organic brewing waste to intensify the destruction of oil pollution in the soil. The experiment was carried out on model samples of oil-contaminated soils with oil concentrations varying from 1000 to $20,000 \mathrm{mg} / \mathrm{kg}$ [Plaza et al. 2005] by introducing brewing waste into the soil as an ameliorant and planting perennial plants. Periodically, in the course of the experiment, the mass fraction of oil in experimental samples was determined to estimate the dynamics of oil destruction. In addition, the dynamics of sprouting and development of plants in the samples was monitored.

The authors have performed two experiments in laboratory conditions. The first experiment took start on November 5, 2019; podzolic soils widely spread in the European part of Russia were used as the object of research. 5 model samples were produced to simulate oil pollution of the soil. The mass of soil in each sample amounted to 700 grams. One sample was used as a control: the oil concentration was $3000 \mathrm{mg} / \mathrm{kg}$ and no organic brewing waste was added. Organic brewing wastes were added to the other model samples, with the oil concentrations of $3000,5000,10,000$ and $20,000 \mathrm{mg} / \mathrm{kg}$ in them, respectively.

The second experiment took start on November 28,2019 . The object of the study also was podzolic soils. 7 model samples were prepared for this experiment with 600 grams of soil in each. Two model samples were used for control with the oil concentration of $2000 \mathrm{mg} / \mathrm{kg}$ and $1000 \mathrm{mg} / \mathrm{kg}$, respectively, and no organic brewing waste added. Organic brewing wastes were added to the rest of the experimental samples, and concentrations of oil in them were 1000, 2000, 3000,5000 and $10,000 \mathrm{mg} / \mathrm{kg}$, respectively.

In both experiments, the authors used light oil of Bazhenovsky field with density of $0.8 \mathrm{~g} / \mathrm{cm}^{3}$ and resin content of $1.2 \mathrm{~g} / \mathrm{kg}$, asphaltenes of $0.8 \mathrm{~g} / \mathrm{kg}$ and sulphur of $0.21 \mathrm{mg} / \mathrm{kg}$ as oil pollutant [Artyukh 2014].

Dry sparging with the humidity of $10.64 \%$ and kieselguhr mud with the humidity content of $63.0 \%$ was supplied by the "Baltika Breweries" Company for the needs of the experiment.

Red clover (Trifolium pratense L.) was used as perennial plants in the experiment in order to reveal the effect of organic wastes of the brewing industry on the vegetation of plants and to determine the phytotoxicity of organic brewing wastes [Silva et al. 2009].

\section{First experiment procedure}

1. The soil, dried at room temperature to an airdry state, was thoroughly cleaned of roots, and sifted through a sieve with the sieve size of $1 \mathrm{~mm}$ [Nagornov and Kremcheeva 2017]. Then, model samples of oil-contaminated soils with oil mass concentrations of 3000 , $5000,10,000$ and $20,000 \mathrm{mg} / \mathrm{kg}$ were prepared on the basis of the obtained soil, which corresponded to the introduction of oil to the samples in the amount of 2.1, 3.5, 7, 14 grams, respectively. One sample was used for control: it was a sample with contaminated soil (oil concentration of $3000 \mathrm{mg} / \mathrm{kg}$ ) with no brewing waste added.

2. Sparging and kieselguhr were manually mixed in the 1:1 ratio [Kumar et al. 2015]. The resulting mixture of organic brewing waste was added to each sample in an amount of $30 \%$ of the soil mass, i.e., 210 grams of organic waste for each sample. No organic waste was added to the control sample. The samples were mellowed and watered as needed throughout the experiment [Rhykerd et al. 1999].

3. Red clover was planted in each sample. The seeding rate was $10 \mathrm{~g} / \mathrm{m}^{2}$ [Pashkevich et al. 2019]. The optimum sowing depth for germination and rooting was $1 \mathrm{~cm}$. The main diagnostic indicators were the general appearance of the plant, the rate of growth, and bruises. The container area was 95 sq. cm (0.0095 sq. m); respectively, seeds were sown in an amount of $0.1 \mathrm{~g}$ on each sample.

In the course of the first experiment, an inhibitory effect on germination of clover seeds was noted in the samples with a mixture of beer waste, which can be explained by the reproduction of mold fungi [Dashko and Shidlovskaya 2016, O'Brien et al. 2017]. This effect can have a considerable impact on the degree of oil products degradation and on the intensity of perennial plant germination and progress. In order to avoid an inhibitory effect, a second experiment was carried out with biofungicide pre-treatment of soil to prevent possible mould reproduction [Mammadov and Khalilova 2016]. 


\section{Second experiment procedure}

1. The soil, dried at room temperature to an airdry state, was thoroughly cleaned of roots, and sifted through a sieve with the sieve size of $1 \mathrm{~mm}$ [Nagornov and Kremcheeva 2017]. Then, model samples of oil-contaminated soils with oil mass concentrations of 1000, 2000, 3000,5000 , and $20,000 \mathrm{mg} / \mathrm{kg}$ were prepared on the basis of the obtained soil, which corresponded to the introduction of oil to the samples in the amount of $0.6,1.2,1.8,3,6$ grams, respectively. Two samples were used for control: these were samples with contaminated soil (oil concentration of 1000 and $2000 \mathrm{mg} / \mathrm{kg}$ ) with no brewing waste added.

2. Biofungicide (phytosporin) in powder form based on hay bacillus was used for the prevention of mould. As directed by the instructions, to treat $1 \mathrm{sq}$. $\mathrm{m}$ of soil, $5 \mathrm{~g}$ of powder must be diluted in 10 liters of water. Approximate surface area of the container was 118 sq. cm; $100 \mathrm{ml}$ of solution is enough for treatment of this surface. The soil was treated with the obtained solution until the mixture of organic brewing wastes was introduced. The approximate surface area of the container was 118 square centimeters, 100 milliliters of solution is sufficient to treat this surface. The soil had been treated with the resulting solution before the mixture of organic brewing waste was added to it.

3. Sparging and kieselguhr were manually mixed in a 1:1 ratio [Kumar et al. 2015]. The resulting mixture of organic brewing waste was added to each sample in an amount of $30 \%$ of the soil mass, which amounted to 180 grams of organic waste for each sample. The samples were mellowed and watered as needed throughout the experiment [Rhykerd et al. 1999].

4. Red clover was planted in each sample. The seeding rate is $10 \mathrm{~g} / \mathrm{m}^{2}$ [Pashkevich et al. 2019]. The optimum sowing depth for germination and rooting is $1 \mathrm{~cm}$. The main diagnostic indicators are the general appearance of the plant, the rate of growth, and bruises. The area of the container was 118 sq. cm (0.0118 sq. meters), respectively; seeds were sown in the amount of 0.12 grams on each sample.

The method of X-ray fluorescence analysis was used to analyze the quantitative composition of the soil before and after the experiment according to the GOST 33850-2016 "Soil method. Determination of the chemical composition by X-ray fluorescence spectrometry" [GOST 33850-2016 ...].

\section{RESULTS AND DISCUSSION}

The first experiment to determine the efficiency of using organic brewing wastes for the intensification of the oil destruction process in the soil lasted for 3.5 months. In the course of the experiment, the dynamics of the decrease in the concentration of oil in the soil with the addition of brewing waste (model sample 1) was assessed in comparison with the control sample. The results of assessing the dynamics of oil destruction in the soil in the first experiment are shown in Table 2.

In Table 2, the results of oil concentration measurement in the soil of the model sample were recalculated by multiplying by 1.3 factor, which compensates the decrease of initial oil concentration in the soil due to natural dilution with organic brewing waste added to the model sample in the amount of $30 \%$ of the sample weight. This operation was carried out for the convenience of comparison of oil destruction dynamics in the soil and the intensity of its concentration decrease in the model sample 1 as compared to the control sample.

As it is seen from the presented table, the decrease of oil concentration in the soil is more intensive in the model sample in comparison with the control one; by the second month, the difference of oil concentrations in the samples is $60 \%$. However, by the fourth month of the experiment, the dynamics of oil destruction in the model sample decreases and by the end of the experiment, the difference in oil concentrations in the samples is about $15 \%$.

In addition, in the course of the first experiment, the effectiveness of using brewing waste in the process of bioremediation was assessed at various initial concentrations of oil in the soil; the results are shown in Table 3.

In Table 3 the results of quantitative determination of oil content in the soil are presented with the account of dilution of the model samples on the first day of the experiment with organic waste, which, in its turn, led to an initial decrease in oil concentration in the model samples by $23 \%$ due to mechanical dilution.

On the basis of the data obtained as a result of the first experiment, a graph of oil content dependence on time was compiled for the entire period of the experiment; it is shown in Figure 1.

The resulting graph illustrates the dynamics of oil content reduction in the soil during the first experiment. The first experiment showed a 
Table 2. The results of assessing the dynamics of oil destruction in soil

\begin{tabular}{|l|c|c|c|c|c|}
\hline \multirow{2}{*}{ Sample } & \multicolumn{5}{|c|}{ Concentration of oil in soil, $\mathrm{mg} / \mathrm{kg}$} \\
\cline { 2 - 6 } & Initial (05.11.2019) & 25.11 .2019 & 05.12 .2019 & 10.01 .2020 & 20.02 .2020 \\
\hline Control sample & 3000.00 & 931.00 & 774.00 & 370.17 & 281.10 \\
\hline Model sample 1 & 3000.00 & 988.00 & 483.57 & 316.11 & 248.29 \\
\hline
\end{tabular}

significant decrease in oil concentration in the first 3 weeks as a result of microorganisms' activity.

In addition, it should be noted that with increasing concentration of initial contamination of the sample there is a decrease in the activity of microorganisms and in the efficiency of oil biodegradation in the soil, which affects the overall efficiency of bioremediation. While in model sample 4 the oil content decreases by $62 \%$ by the end of the experiment, in model sample 1 it decreases by $92 \%$.

As already mentioned, an inhibitory effect on the germination of clover seeds was noted in the samples with a mixture of brewery waste in the course of the first experiment. It can be explained by the reproduction of mould fungi. To exclude the influence of mould on the degree of degradation of oil products, as well as on the intensity of sprout and development of perennial plants, it was decided to conduct a second experiment.

To exclude the possible mould reproduction and its inhibitory effect on the bioremediation process, during the second experiment, all model samples were pretreated with biofungicide. The second experiment to determine the efficiency of using organic brewing waste to intensify the process of oil destruction in the soil was carried out for almost 4 months. In the process of the experiment, the dynamics of the decrease in the concentration of oil in the soil with the addition of brewing waste (model samples 1 and 2) was estimated in comparison with control samples 1 and 2; the results are shown in Table 4.

The results of measuring the concentration of oil in the soil of the model sample in Table 4 were also recalculated by multiplying by a factor of 1.3 , which made it possible to compensate for the decrease in the initial concentration of oil in the soil due to natural dilution with organic brewing waste, which was added to the model sample in an amount of $30 \%$ of the sample weight.

In the course of the second experiment, the efficiency of using brewing waste in the process of bioremediation was also assessed at different initial concentrations of oil in the soil; the results are shown in Table 5.

Table 3. The results of evaluating the efficiency of using brewing waste in the process of bioremediation at various initial concentrations of oil

\begin{tabular}{|c|c|c|c|c|c|c|}
\hline \multirow{2}{*}{ Sample } & \multicolumn{7}{|c|}{ Concentration of oil in soil, $\mathrm{mg} / \mathrm{kg}$} \\
\cline { 2 - 7 } & $\begin{array}{c}\text { Initial } \\
(05.11 .2019)\end{array}$ & $\begin{array}{c}\text { Diluted } \\
(05.11 .2019)\end{array}$ & 25.11 .2019 & 05.12 .2019 & 10.01 .2020 & 20.02 .2020 \\
\hline Model sample 1 & 3000.00 & 2307.69 & 760.00 & 371.98 & 243.16 & 190.99 \\
\hline Model sample 2 & 5000.00 & 3846.15 & 1496.92 & 940.99 & 817.35 & 754.95 \\
\hline Model sample 3 & 10000.00 & 7692.31 & 2520.00 & 2174.95 & 1817.08 & 1582.97 \\
\hline Model sample 4 & 20000.00 & 15384.62 & 6919.56 & 5970.55 & 5538.46 & 5097.91 \\
\hline
\end{tabular}

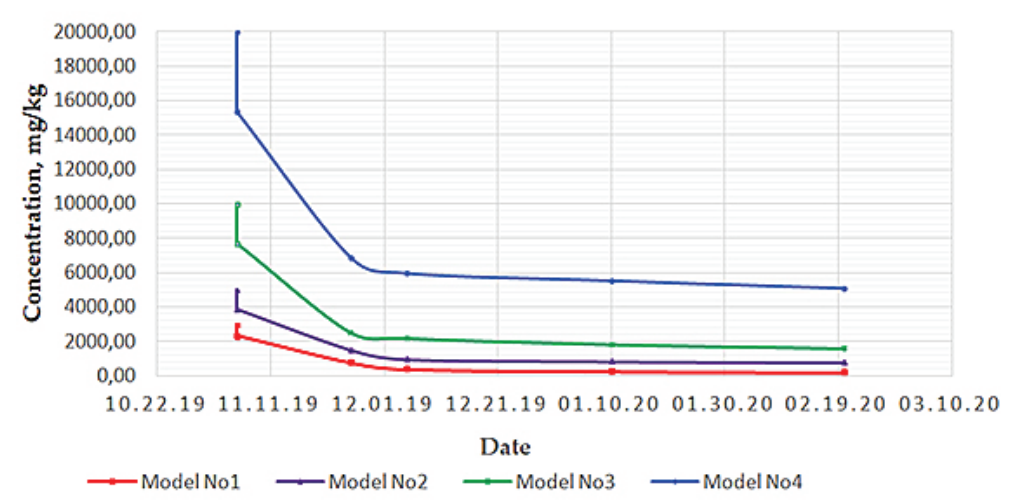

Figure 1. A graph of the dependence of the oil content on time for the period of the experiment 
All results of quantitative determination of oil content in the soil are presented in Table 5 with the account of dilution of model samples on the first day of the experiment with organic waste, which, in its turn, led to an initial $23 \%$ decrease in oil concentration in the model samples due to mechanical dilution.

Based on the data obtained in the course of the second experiment, 2 graphs of the dependence of the oil content on the time during the experiment were compiled. The first graph, shown in Figure 2, displays a comparative characteristic of the change in oil concentration in control sample 1 and model sample 1 .

The graph shows that the efficiency of oil biodegradation in the control sample (efficiency is $96.8 \%$ ) is slightly lower than in the model sample (efficiency is $97.4 \%$ ). At the end of the experiment, the concentration of oil in the model sample was $20 \%$ lower than in the control sample.

The second graph, shown in Figure 3, displays a comparative characteristic of the change in oil concentration in control sample number 2 and model sample number 2 .

The graph shows that the efficiency of oil biodegradation in the control sample (efficiency is $85 \%$ ) is slightly lower than in the model sample (efficiency is $87.8 \%$ ). At the end of the experiment, the concentration of oil in the model sample was also $20 \%$ lower than in the control sample.

Throughout the experiment, there was a positive dynamics of oil concentration reduction; with the introduction of a mixture of sparging and spent kieselguhr in the contaminated soil, the degree of oil destruction increased by 1.5 times. At low concentrations, the dynamics of decrease continued in the course of all 4 months, while the difference between the control and model samples remained at the level of $20 \%$, which also confirmed the effectiveness of the use of brewing waste for reclamation of oil-contaminated soils.

Thus, the acceleration of the processes of destruction of oil hydrocarbons occurred due to the dilution of the soil mixture, activity of microorganisms, and maintenance of a favorable air and water regime in contaminated soils, which reduced the negative toxic effect of oil hydrocarbons on the aboriginal oil oxidizing microflora.

In the second experiment, lower concentrations of model contamination were taken. Soil treatment with biofungicide reduced the growth of mould; although the inhibitory effect was still preserved, in comparison with the first experiment, in the samples with a mixture of kieselguhr and sparging; minor germination of clover seed was registered. On the control sample of soil with waste mixture the growth rate was higher than on the model samples, which could be explained by the depressing effect of oil pollution.

One soil sample before the experiment and model samples with the maximum concentration of oil products in both experiments, after their completion, were subjected to semi-quantitative chemical analysis, which was carried out by X-ray fluorescence spectrometry on a Shimadzu XRF 1800 X-ray fluorescence spectrometer according to the GOST 33850-2016 "Soil method. Determination of the chemical composition by X-ray

Table 4. The results of assessing the dynamics of oil destruction in soil

\begin{tabular}{|l|c|c|c|c|c|c|}
\hline \multirow{2}{*}{ Sample } & \multicolumn{7}{|c|}{ Concentration of oil in soil, $\mathrm{mg} / \mathrm{kg}$} \\
\cline { 2 - 7 } & 28.11 .2019 & 05.12 .2019 & 17.12 .2019 & 28.12 .2019 & 05.02 .2020 & 12.03 .2020 \\
\hline Control sample 1 & 1000.00 & 453 & 210.00 & 168.00 & 67.23 & 31.67 \\
\hline Model sample 1 & 1000.00 & 362.4 & 169.00 & 135.17 & 52.46 & 26.00 \\
\hline Control sample 2 & 2000.00 & 929 & 427.00 & 371.50 & 334.88 & 301.00 \\
\hline Model sample 2 & 2000.00 & 744.39 & 341.83 & 304.20 & 272.60 & 244.33 \\
\hline
\end{tabular}

Table 5. The results of evaluating the efficiency of using brewing waste in the process of bioremediation at various initial concentrations of oil

\begin{tabular}{|c|c|c|c|c|c|c|c|}
\hline \multirow{2}{*}{ Sample } & \multicolumn{7}{|c|}{ Concentration of oil in soil, $\mathrm{mg} / \mathrm{kg}$} \\
\cline { 2 - 8 } & $\begin{array}{c}\text { Initial } \\
28.11 .2019\end{array}$ & $\begin{array}{c}\text { Diluted } \\
(28.11 .2019)\end{array}$ & 05.12 .2019 & 17.12 .2019 & 28.12 .2019 & 05.02 .2020 & 12.03 .2020 \\
\hline Model sample1 & 1000.00 & 769.23 & 278.77 & 130.00 & 103.98 & 40.35 & 20.00 \\
\hline Model sample 2 & 2000.00 & 1538.46 & 572.61 & 262.95 & 234.00 & 209.69 & 187.95 \\
\hline Model sample 3 & 3000.00 & 2307.69 & 918.02 & 615.00 & 480.00 & 433.08 & 387.95 \\
\hline Model sample 4 & 5000.00 & 3846.15 & 1620.45 & 832.95 & 678.98 & 635.88 & 623.98 \\
\hline Model sample 5 & 10000.00 & 7692.31 & 3628.46 & 1785.56 & 1675.00 & 1659.69 & 1600.00 \\
\hline
\end{tabular}




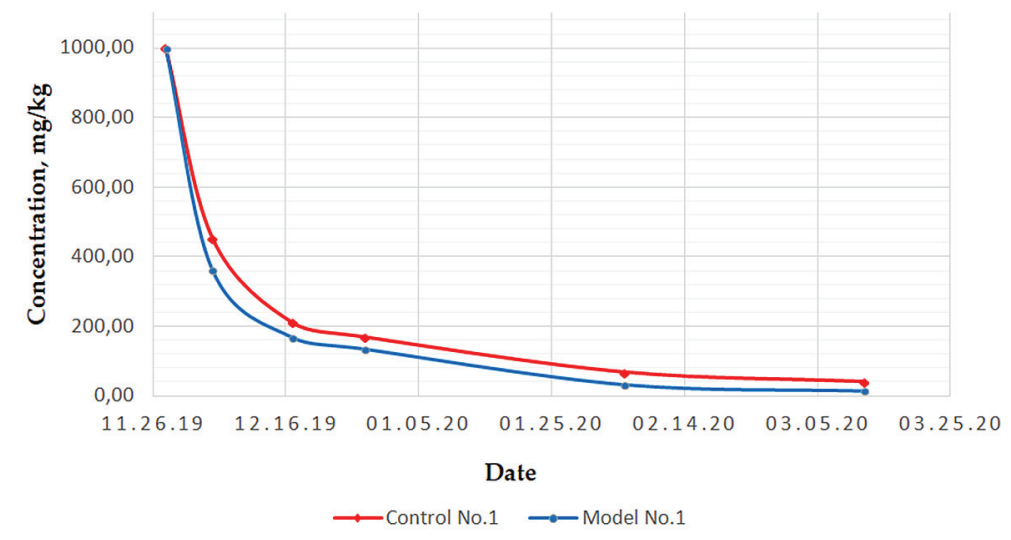

Figure 2. A comparative characteristic of the change in oil concentration in control sample number 1 and model sample number 1

fluorescence spectrometry" [GOST 33850-2016 ...]. All three measurements showed that the samples are based on an aluminosilicate matrix with the main components in the form of $\mathrm{CaO}, \mathrm{MgO}$, $\mathrm{Fe} 2 \mathrm{O} 3$ and $\mathrm{MnO}$, the content of harmful components was below the detection limit or below the standard values, including $\mathrm{S}$ was present in insignificant amounts, which is apparently associated with oil pollution

Based on the obtained results of sowing red clover and the dynamics of its growth, it can be concluded that a mixture of organic waste from the brewing industry significantly slows down the vegetation of clover. It should be noted that the reviewed sources did not cover the issues of the possible Based on the results of red clover sowing and its growth dynamics, we can conclude that a mixture of organic waste from the brewing industry significantly slows down the clover vegetation. At the same time, it should be noted that the considered sources did not cover the issues of possible phytotoxic effect of organic waste of brewing on vegetation of plants. Phytotoxicity may increase saprophyte micromycetes in the root zone, the growth of which may be stimulated by the introduction of organic substances; in this regard, several assumptions can be made:

- It is not advisable to use raw brewing waste directly for soil fertilization, but to use it first for composting to reduce moisture and organic content;

- It is necessary to age a mixture of oil-contaminated soils and organic waste to destroy pollution and reduce the concentration of nitrogencontaining substances due to the activity of microflora, and then plant the plants;

- It is necessary to experiment with alternative species of perennial plants on model samples with the same level of contamination to determine the most optimal ones for reclamation works.

It is recommended to continue research on the impact of brewery waste on the growth and progress of plants according to the above assumptions in view of the efficiency of oil pollution destruction.

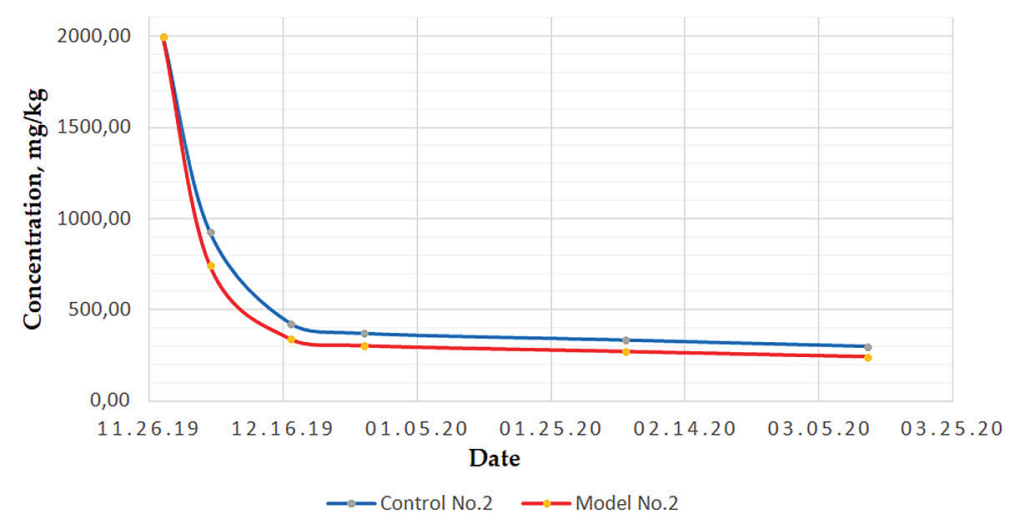

Figure 3. A comparative characteristic of the change in oil concentration in control sample number 2 and model sample number 2 


\section{CONCLUSION}

The scientific research carried out by the authors allows drawing the following conclusions:

1. The technologies of in-situ bioremediation for the purpose of purification of oil-contaminated lands have undeniable environmental, technological, and economic advantages, the main of which is to preserve and even increase the organic component of the soil mixture reduced in the course of movement and thermal and chemical treatment of contaminated soils. Conducted model laboratory experiments according to the results of fluorimetric analysis of the degree of oil removal from the soil allow to draw a conclusion that organic wastes of brewing production can be used in the processes of bioremediation of oil-contaminated soils.

2. Sparging and spent kieselguhr contain complexes of nutrients and biologically active substances, which promote the metabolism of crude oil in the soil environment due to hydrocarbon oxidizing microorganisms. However, the efficiency of reducing the concentration of oil pollution according to the proposed technology due to mechanical dilution with brewing waste and increasing the activity of microorganisms varies from $75 \%$ to $98 \%$ with an initial pollution range varying from 1000 to $20,000 \mathrm{mg} / \mathrm{kg}$. In this regard, it is necessary to take into account the level of initial soil contamination and, if necessary, combine bioremediation with preliminary cleaning of oil-contaminated soils with sorbents in case of long-term contamination or with sorption fiber in case of fresh oil and oil product spills.

3. At low concentrations ( 1000 and $2000 \mathrm{mg} / \mathrm{kg}$ ), the dynamics of decrease continued for all 4 months; at the same time, the difference between the control and model samples remained at the level of $20 \%$, which also confirms the efficiency of application of brewing waste for reclamation of oil-contaminated soils. Not very high efficiency of sparging and spent kieselguhr in the experiment is associated with the soil structure (activity of microorganisms in the control samples shows an initial high content of organic matter) and excess moisture, which is confirmed by the development of mould fungi. In this regard, it is necessary to consider the use of brewing waste for remediation of soils with a low content of nutrients and low water retention capacity.
4. The tested mixture of organic brewing waste resulted in the formation of mould fungi; the repeated experiment with soil pretreatment with biofungicide reduced the growth of mould, while the inhibitory effect was still preserved. In this regard, we can conclude that it is necessary to apply raw brewing waste directly to fertilize the soil in smaller proportions, or in arid climatic conditions of the reclaimed region. It is necessary to age a mixture of oil-contaminated soils and organic waste to destroy the pollution and reduce the concentrations of nitrogen containing substances through the activity of microflora, and then to carry out planting. In this case, the duration of purification will take 2 or 3 vegetation periods depending on the initial oil concentration in the contaminated soil.

\section{REFERENCES}

1. Abioye O.P., Agamuthu P., Abdul Aziz A.R. 2012. Biodegradation of Used Motor Oil in Soil Using Organic Waste Amendments. Biotechnology Research International, paper ID 587041.

2. Agamuthu P, Abioye O.P., Aziz A.A. 2010. Phytoremediation of soil contaminated with used lubricating oil using Jatropha curcas. Journal of Hazardous Materials, 179(1), 891-894.

3. Akhmadiev M.V., Rudakova L.V. 2013. Analysis of methods for the restoration of oil-contaminated lands (Russian and foreign experience). Bulletin PNIPU. Environmental protection, transport, life safety, 1, 16-25.

4. Alekseenko V.A., Bech J., Alekseenko A.V., Shvydkaya N.V., Roca N. 2018. Environmental impact of disposal of coal mining wastes on soils and plants in Rostov Oblast, Russia. Journal of Geochemical Exploration, 184, 261-270.

5. Artyukh E.A. 2014. Prospects for the use of biosorbents for cleaning water bodies during the elimination of emergency oil spills. Bulletin of SPbGTI (TU), 26, 58-66.

6. Dadashev M.N., Kobelev K.V., Filenko D.G., Vinokurov V.A., Kapustin M.A., Radzhabov Z.M., Prinz N.R., Krupnov V.A. 2011. Environmental safe brewing waste processing technology. Beer and drinks, 5, 18-20.

7. Dashko R.E., Shidlovskaya A.V. 2016. Impact of microbial activity on soil properties. Canadian Geotechnical Journal, 53, 1386-1397.

8. Dessalew G., Beyene A., Nebiyu A., Ruelle M. 2017. Use of industrial diatomite wastes from beer production to improve soil fertility and cereal yields. Journal of Cleaner Production, 157, 22-29. 
9. Filonov A.V., Krampit M.A., Romanenko V.O. 2017.Modern state and promising directions of using secondary material resources of the food industry. Fundamental research, 5, 215-219.

10. Gaysina D.R. 2016. Analysis of the causes of emergency situations on trunk pipelines. Bulletin of Kazan Technological University, 19(14), 129-130.

11. GOST 17.4.4.02-84. Protection of Nature. Soils. Methods for sampling and preparation of samples for chemical, bacteriological, helminthological analysis.

12. GOST 33850-2016. Soil method. Determination of the chemical composition by X-ray fluorescence spectrometry.

13. Goswami M, Chakraborty P, Mukherjee K. 2018. Bioaugmentation and biostimulation: a potential strategy for environmental remediation. Journal of Microbiology and Experimentation, 6(5), 223-231.

14. HDPE F 16.1: 2.21-98. Quantitative chemical analysis of soils. Methods for measuring the mass fraction of oil products in soil and soil samples by the fluorimetric method using a fluid analyzer «Fluorat-02».

15. Ibragimov N.G., Gareev R.M., Ismagilov I.F., Kubarev P.N., Shaydullina I.A. 2017. Regulatory support for reclamation of disturbed and oil-contaminated soils in Tatneft PJSC assets. Neftyanoe Khozyaystvo - Oil Industry, 5, 74-77.

16. Kireev S.B., Litvinenko V.S., Telegin A.N. 2014. The modern technology of seismic prospecting with the use of reflection method applied to oil and gas exploration. 6th Saint Petersburg International Conference and Exhibition on Geosciences 2014: Investing in the Future, 242-246.

17. Kovshov S.V., Skamyin A.N. 2017. Treatment of agricultural wastes with biogas-vermitechnology. Environmental Earth Sciences, 19, 2-14.

18. Krauss M., Wilcke W. 2007. Sorption Strength of Persistent Organic Pollutants in Particle-size Fractions of Urban Soils. Soil Science Society of America Journal, 66, 430-437.

19. Kumar R., Das A.J., Juwarkar A.A. 2015. Reclamation of petrol oil contaminated soil by rhamnolipids producing PGPR strains for growing Withania somnifera a medicinal shrub. World Journal of Microbiology and Biotechnology, 31(2), 307-313.

20. Litvinenko V.S., Kozlov A.V., Stepanov V.A. 2017. Hydrocarbon potential of the Ural-African transcontinental oil and gas belt. Journal of Petroleum Exploration and Production Technology, 7(1), 1-9.

21. Mammadov V.A., Khalilova H.Kh. 2016. The ways of transformation of salt production from the saline lakes of Apsheron Peninsula. Journal of Mining Institute, 222, 809-815.

22. Margesin R., Schinner F. 1999. Biodegradation of diesel oil by cold-adapted microorganisms in presence of sodium dodecyl sulfate. Chemosphere. Vol.
38(15), 3463-3472.

23. Matveeva V., Lytaeva T., Danilov A. 2018. Application of steel-smelting slags as material for reclamation of degraded lands. Journal of Ecological Engineering, 19(6), 97-103.

24. Mukherjee A.K., Bordoloi N.K. 2011. Bioremediation and reclamation of soil contaminated with petroleum oil hydrocarbons by exogenously seeded bacterial consortium: A pilot-scale study. Environmental Science and Pollution Research, 18(3), 471-478.

25. Nagornov D.O., Kremcheeva D.A. 2017. Assessment of gravity component of moisture flow in raw peat in conditions of convective and radiative-convective heat input. Journal of Industrial Pollution Control, 33(1), 749-752.

26. Nizamzade T.N. 2014. Reclamation of oil-contaminated soils of the Absheron peninsula for the purpose of cadastral assessment. Environmental Engineering, 4, 20-24.

27. O’Brien P.L., DeSutter T.M., Ritter S.S., Casey F.X.M., Wick A.F., Khan E., Matthees H.L. 2017. A large-scale soil-mixing process for reclamation of heavily disturbed soils. Ecological Engineering, 109, 84-91.

28. Ogugbue C.J., Mbakwem-Aniebo C., Solomon L. 2017. Efficacy of brewery spent grain and rabbit droppings on enhanced ex situ bioremediation of an aged crude oil contaminated soil. International Journal of Applied Microbiology and Biotechnology Research, 5(4), 27-39.

29. Oruru J.A. 2014. Is the use of Brewery spent grain in bioremediation of diesel contaminated soil sustainable? Doctoral thesis, University of Sunderland.

30. Panchenko L., Muratova A., Dubrovskaya E., Golubev S., Turkovskaya O. 2018. Dynamics of natural revegetation of hydrocarbon-contaminated soil and remediation potential of indigenous plant species in the steppe zone of the southern Volga Uplands. Environmental Science and Pollution Research, 25(4), 3260-3274.

31. Pashkevich M.A., Petrova T.A. 2016. Creation of a system for industrial environmental monitoring in hydrocarbon production and transporting companies of Western Siberia. Journal of Mining Institute, 221, 737-741.

32. Pashkevich M.A., Petrova T.A., Rudzisha E. 2019. Lignin Sludge Application for Forest Land Reclamation: Feasibility Assessment. Journal of Mining Institute, 235, 106-112.

33. Pietron J., Chalov S.R., Chalova A.S., Alekseenko A.V., Jarsjo J. 2017. Extreme spatial variability in riverine sediment load inputs due to soil loss in surface mining areas of the Lake Baikal basin. Catena, 152, 82-93.

34. Plaza G., Nalecz-Jawecki G., Ulfig K., Brigmon R.L. 2005. The application of bioassays as indicators of 
petroleum-contaminated soil remediation. Chemosphere, 59(2), 289-296.

35. Rhykerd R.L., Crews B., McInnes K.J., Weaver R.W. 1999. Impact of bulking agents, forced aeration, and tillage on remediation of oil-contaminated soil. Bioresource Technology, 67(3), 279-285.

36. Robichaud K., Lebeau M., Martineau S., Amyot M. 2019. Bioremediation of engine oil contaminated soil using local residual organic matter. PeerJ, paper ID e7389.

37. Rudenko E.Yu. 2015. Bioremediation of oil-contaminated soils with organic components of food (brewing) waste. Doctoral thesis, Samara State Technical University.

38. Russ W, Mortel H., Meyer-Pittroff R., Babeck A. 2006. Kieselguhr sludge from the deep bed filtration of beverages as a source for silicon in the production of calcium silicate bricks. Journal of the European Ceramic Society, 26, 2547-2559.

39. Semin A., Grevtsev N., Egoshina O. 2017. Systems approach in modeling production and consumption of peat products. Journal of Environmental Management and Tourism, 8(5), 961-971.

40. Semyachkov A.I., Slawikowskaja Y.O., Pochechun V.A. 2018. Methodological features of the assessment of economic damage from adverse environmental consequences in conditions of territories with a developed mining complex. Ecology and Industry of Russia, 22(4), 46-51.

41. Senyene U., Maria P., Mfoniso P. 2017. Bacterization of Biostimulant (Brewers Spent Grains) on Hydrocarbon Degradation of Crude Oil Contaminated Garden Soil. Journal of Applied Microbiology and Biotechnology, 5(4), 1-19.

42. Silva I.S., da Costa dos Santos C.R., de Menezes A.F., de Faria E., Franciscon M., Grossman L. Regina. 2009. Durrant bioremediation of a polyaromatic hydrocarbon contaminated soil by native soil microbiota and bioaugmentation with isolated microbial consortia. Bioresource Technology, 100, 4669-4675.

43. Song X., Li X., Wang Y. Hu X. 2011. Long-term phytoremediation process of diesel oil-contaminated soil. Advanced Materials Research, 414 p. 280-283.

44. State report «About condition and protection of the environment of the Russian Federation in 2018». URL: http://gosdoklad-ecology.ru/2018/\%20 (25.08.2020).

45. Tsombueva B.V. 2014. The use of natural materials as sorbents for cleaning soils from oil pollution. Modern problems of science and education, 6, 1-7.

46. Welch M. 2014. Selection criteria for power generation systems to minimise environmental impact. Society of Petroleum Engineers - SPE Heavy and Extra Heavy Oil Conference, 845-856.

47. Xu J.G., Johnson R.L. 1995. Root growth, microbial activity and phosphatase activity in oil-contaminated, remediated and uncontaminated soils planted to barley and field pea. Plant and Soil, 173(1), 3-10.

48. Yankevich M.I., Khadeeva V.V., Murygina V.P. 2015. Soil bioremediation: yesterday, today, tomorrow. Biosphere: an interdisciplinary scientific and applied journal, 7(2), 199-208.

49. Yatsenko V.S., Strizhakova E.R., Zinnatshina L.V., Vasilyeva G.K. 2014. A method for reducing environmental risks during the bioremediation of oilcontaminated soils. Problems of risk analysis, (5), 4-17.

50. Zambrano J., Kovshov S., Lyubin E. 2018. Assessment of anthropogenic factor of accident risk on the main oil pipeline Pascuales - Cuenca in Ecuador. Journal of Applied Engineering Sciences, 16(3), 307-312. 